\title{
Potensi Pemanfaatan Limbah Ampas Kelapa Sebagai Sumber Pangan Atau Bahan Substitusi Makanan Kesehatan
}

\author{
Potential Utilization Of Coconut Pulp Waste As A Food Source Or Health Food Substitution \\ Material
}

Delima Panjaitan

Prodi Teknologi Hasil Pertanian Fakultas Pertanian Universitas Katolik Santo Thomas Medan Email: delimapanjaitan09@yahoo.co.id

\begin{abstract}
Coconut plants (Cocos nucifera, L) are a type of palm plant that has a multi-function, because almost all parts of the plant can be used to meet the needs of the community. In addition, waste from the processing of coconut fruit in the form of coconut pulp can still be used. The use of coconut pulp as a food source or health food substitution material, so far has not been done much. Research is a literature study using descriptive analysis methods and data collection using documentation techniques. The utilization of coconut pulp waste as a food source or health food substitution material, is very potential from the aspect of productivity, health aspects and economic and ecological benefits
\end{abstract}

Keywords: Coconut pulp waste, potential, food sources

\begin{abstract}
ABSTRAK
Tanaman kelapa (Cocos nucifera $L$ ) termasuk jenis tanaman palma yang memiliki multi fungsi, karena hampir semua bagian dari tanaman tersebut dapat dimanfaatkan untuk memenuhi kebutuhan masyarakat, Selain dari itu, limbah dari pengolahan buah kelapa ini dalam bentuk ampas kelapa masih dapat dimanfaatkan. Pemanfaatan ampas kelapa sebagai sumber pangan atau bahan substitusi makanan kesehatan selama ini belum banyak dilakukan. Penelitian bersifat studi literatur dengan menggunakan metode analisis deskriptif dan pengumpulan data menggunakan teknik dokumentasi. Pemanfaatan dari limbah ampas kelapa ini sebagai sumber pangan atau bahan substitusi makanan kesehatan, sangat berpotensi ditinjau dari aspek produktivitasnya, aspek kesehatan dan manfaat ekonomi dan ekologisnya.
\end{abstract}

Kata Kunci: Limbah ampas kelapa, potensial, sumber pangan

\section{PENDAHULUAN}

Ampas kelapa adalah sejenis limbah organik dari hasil pengolahan minyak kelapa yang sekarang ini belum dimanfaatkan secara maksimal. Selama ini ampas kelapa sebagian besar dibuang begitu saja disembarang tempat sehingga meyebabkan pencemaran lingkungan atau dimanfaatkan tetapi masih sebatas dijadikan pakan ternak, tetapi masih sebatas dijadikan pakan ternak.

Pemanfaatan limbah sebagai pakan ternak merupakan upaya bijaksana dalam mengatasi pencemaran lingkungan. Limbah sebagai bahan pakan ternak memiliki kualitas yang rendah akan tetapi memiliki harga yang murah dan ketersediannya selalu 
berkesinambungan (Murni et al., 2008; Widiastuti et al., 2015, Rousmaliana dan Pemanfaatan ampas kelapa sebagai sumber pangan atau bahan substitusi makanan kesehatan selama ini belum banyak terungkap. Meskipun ampas kelapa merupakan hasil samping pembuatan santan, namun memiliki kandungan nutrisi dan serat kasar yang cukup tinggi. Serat pangan tidak dapat dicerna dan tidak diserap oleh saluran pencernaan manusia, tetapi memiliki fungsi yang sangat penting bagi pemeliharaan kesehatan, pencegahan penyakit dan sebagai komponen penting dalam terapi gizi (Yulvianti et al., 2015).

Disamping itu potensi pemanfaatan limbah ampas kelapa ini dijadikan sebagai sumber pangan sangat menjanjikan mengingat produktifitas kelapa di Indonesia cukup tinggi rata rata mencapai 19,5 miliar butir per tahun atau setara dengan 12,02 miliar ton daging kelapa per tahun. Setiap pengolahan $100 \mathrm{~kg}$ daging kelapa untuk pembuatan minyak murni dihasilkan $19,5 \mathrm{~kg}$ ampas kelapa (Putri, 2014). Karena itu pemanfaatan ampas kelapa sebagai sumber pangan menjadi salah satu alternatif yang sangat potensial, bernilai ekonomis dan ekologis dan sekaligus mendukung diversifikasi pangan menuju ketahanan pangan nasional.

\section{METODE PENELITIAN}

Penelitian bersifat studi literatur dengan menggunakan metode analisis deskriptif kualitatif dan pengumpulan data menggunakan teknik dokumentasi.

\section{HASIL DAN PEMBAHASAN}

Tanaman kelapa sebagai tanaman tropis merupakan tanaman komoditi yang tumbuh dan berkembang dengan baik di Indonesia. Secara khusus, tanaman ini tumbuh di sepanjang pasir pantai dan secara umum dapat tumbuh di dataran tinggi serta lereng gunung. Tanaman kelapa termasuk jenis Palmae yang berumah satu (monokotil). Tanaman kelapa (Cocos nucifera $L$ ) termasuk jenis tanaman yang
Septiani, 2019)

memiliki berbagai banyak fungsi, hal ini karena hampir semua bagian dari tanaman tersebut dapat dimanfaatkan untuk memenuhi kebutuhan pangan masyarakat (Saepulah et al., 2017). Bahkan karena semua bagian tanaman kelapa ini dapat dimanfaatkan dan mempunyai nilai ekonomi, maka tidak mengherankan bahwa julukan yang diberikan bagi pohon kelapa ini sangat hebat yaitu sebagai "The tree of life" yang berarti pohon kehidupan (Branton \& Blake, 1983 dalam Mardiatmoko, 2018). Selain dari itu, limbah dari buah kelapa ini dalam bentuk ampas kelapa sebagai sisa buangan dari pengambilan santan masih dapat dimanfaatkan. Pemanfaatan dari limbah ampas kelapa ini sangat berpotensi ditinjau dari aspek produktivitasnya, aspek kesehatan dan manfaat ekonomi dan ekologisnya.

\section{Potensi Limbah Ampas Kelapa dari Aspek Produktivitas}

Tanaman kelapa (Cocos nucifera L) banyak dijumpai di Indonesia yang merupakan penghasil kelapa terbesar kedua di dunia, sesudah Philipina (Anggraini 2011). Sebagai negara kepulauan terbesar, Indonesia memiliki kebun kelapa (Cocos nucifera L.) terluas di dunia, seluas 3.566.103 Ha. Produksi pohon kelapa di Indonesia pada tahun 2016 menurut status pengusahaan (1970-2017) mencapai 2.890.735 Ton di antaranya merupakan perkebunan Negara, Swasta dan rakyat. Sebagian besar perkebunan kelapa dibudidayakan oleh rakyat yang tersebar diseluruh pelosok Indonesia. Untuk produksi kelapa menurut area dapat dilihat pada Tabel 1. (Direktorat Jenderal Perkebunan, 2017).

Dari data Tabel 1. total produksi kelapa ada seluas 3.566.103 Ha dengan total produksi 2.890 .734 Ton, jumlah yang sangat potensial untuk menghasilkan limbah ampas kelapa. Dimana ampas kelapa ini dapat dijadikan sebagai sumber pangan atau bahan substitusi makanan kesehatan yang sangat menjanjikan mengingat produktifitas kelapa 
di Indonesia cukup tinggi. Rata-rata mencapai 19,5 miliar butir per tahun atau setara dengan 12,02 miliar ton daging kelapa dihasilkan 19,5 kg ampas kelapa (Prasetyo et al., 2014).

Tabel 1. Luas Areal dan Produksi Kelapa di Indonesia Tahun 2016

\begin{tabular}{llcc}
\hline No & Pulau & $\begin{array}{c}\text { Luas } \\
\text { Lahan } \\
(\mathrm{Ha})\end{array}$ & $\begin{array}{c}\text { Produksi } \\
\text { (Ton) }\end{array}$ \\
\hline 1 & Sumatera & 1.130 .014 & 934.563 \\
2 & Jawa & 816.842 & 627.655 \\
3 & NTT dan & 271.234 & 197.236 \\
& Bali & & \\
4 & Kalimantan & 201.410 & 140.634 \\
5 & Sulawesi & 772.729 & 632.520 \\
6 & Maluku dan & 373.874 & 358.126 \\
& Papua & \\
\hline \multicolumn{4}{l}{ Total 3.566.103 } \\
\hline \multicolumn{4}{l}{ Sumber: Direktorat Jenderal Perkebunan, 2017 }
\end{tabular}

\section{Potensi Pemanfaatan Limbah Ampas Kelapa dari Aspek Kesehatan}

Usaha budidaya tanaman kelapa melalui perkebunan terutama dilakukan untuk memproduksi minyak kelapa yang berasal dari daging buahnya dengan sampingan berupa ampas kelapa. Pada proses pembuatan minyak kelapa murni virgin coconut oil, daging kelapa segar yang telah diparut kemudian dikeringkan dan dipres hingga minyaknya terpisah. Hasil samping dari proses pembuatan minyak kelapa murni adalah ampas kelapa. Ampas kelapa hasil samping pembuatan minyak kelapa murni masih memiliki kandungan protein yang cukup tinggi. Hal ini menyebabkan ampas kelapa berpotensi untuk dimanfaatkan dan diolah menjadi pakan (Anggraini, 2011). per tahun. Setiap pengolahan $100 \mathrm{~kg}$ daging kelapa untuk pembuatan minyak murn

Menurut Yulvianti et al. (2015) hasil samping ampas kelapa juga mengandung protein $23 \%$, karbohidrat $93 \%$ terdiri dari $61 \%$ galaktomanan, 26\% manosa, dan $13 \%$ selulosa. Meskipun ampas kelapa merupakan hasil samping pembuatan santan, namun ampas kelapa memiliki kandungan serat kasar cukup tinggi. Serat pangan ini juga dapat mengontrol pelepasan glukosa seiring waktu, membantu pengontrolan dan pengaturan, diabetes melitus dan obesitas. Serat pangan dalam jumlah yang cukup didalam makanan sangat bagus untuk pencernaan yang baik dalam usus. Serat pangan memberikan efek fisiologis menguntungkan seperti laksasi, mengatur kolesterol darah dan glukosa darah (Gallaher, 2000) serta mencegah risiko kanker kolon (Karouw dan Rindengan, 2008).

Ampas kelapa limbah VCO memiliki kandungan gizi cukup baik, yaitu $30 \%$ bahan kering; 5,24\% emak kasar; 6,44\% protein kasar; $1,55 \%$ abu; $24,82 \%$ serat kasar dan TDN (total digestible nutrient) atau nutrisi yang dapat dicerna sebesar 76,78\% (Liptan, 2006). Dari hasil analisis yang dilakukan di Pusat Studi Pangan dan Gizi, Universitas Gadjah Mada pada tahun 2008, diketahui bahwa ampas VCO memiliki kandungan energi sebesar 4.697,87 $\mathrm{kcal} / \mathrm{kg}$, protein kasar $14,69 \%$, serat kasar $13,76 \%$, lemak kasar $65,69 \%$, kalsium $0,01 \%$, dan fosfor $0,67 \%$ (Tabel 2). Dari data tersebut dapat dilihat bahwa ampas VCO sangat berpotensi untuk digunakan sebagai sumber energi dan lemak (Oktaviana et al. 2010). 
Tabel 2. Analisis Kimia Ampas Kelapa

\begin{tabular}{clc}
\hline No & Jenis Analisa & Ampas VCO \\
\hline 1 & Kadar Air (\%) & 13,20 \\
2 & Kadar Abu (\%) & 1,20 \\
3 & Kadar Lemak (\%) & 28,14 \\
4 & Kadar Protein (\%) & 8,34 \\
5 & Kadar Serat Kasar (\%) & 9,22 \\
6 & Karbohidrat (\%) & 40,00 \\
7 & Kalori (kal/100gr) & 446,9 \\
\hline
\end{tabular}

Sumber: Herawati, et al (2008)

Demikian juga halnya limbah ampas kelapa yang sudah dijadikan pangan olahan seperti tepung, cukup mengandung nutrisi yang baik. Tepung ampas kelapa mengandung kadar air 4,2\%, lemak 9,2\%, protein $12,6 \%$, abu $8,2 \%$, serat $13 \%$, dan karbohidrat $39,1 \%$. Tepung ampas kelapa merupakan bahan pangan sumber serat karena mengandung selulosa cukup tinggi. Dewasa ini, asupan serat menjadi semakin diutamakan dalam membuat formulasi produk pangan karena perannya dalam memperlancar pencernaan dan mengurangi ketersediaan kolesterol di dalam tubuh (Wardani et al., 2017).

Berdasarkan hasil analisis kandungan gizi hasil samping ampas kelapa masih bernilai tinggi bila dimanfaatkan sebagai makanan berkadar lemak rendah yang cocok dikonsumsi oleh golongan konsumen yang kegemukan (obesitas), beresiko tinggi terhadap kolesterol dan jantung koroner. Hasil samping ampas kelapa mengandung selulosa cukup tinggi dapat berperan dalam proses fisiologi tubuh. Selulosa merupakan serat pangan yang tidak dapat dicerna oleh enzim-enzim pencernaan. Serat pangan umumnya terdiri atas kompleks karbohidrat dinding sel tumbuhan, seperti selulosa, hemiselulosa, pektin dan lignin juga polisakarida intraseluler seperti gum dan muscilago yang tidak terhidrolisis oleh enzim pencernaan manusia (Spiller, 2000).

Serat Pangan telah ditunjukkan memiliki peranan penting dalam pencegahan resiko karsinogenesis dan arterosklerosis. Serat pangan ini juga mengontrol pelepasan glukosa seiring waktu, membantu pengontrolan dan pengaturan diabetes melitus dan obesitas (Trinidad et al., 2001).

Serat pangan dalam jumlah yang cukup didalam makanan sangat bagus untuk pencernaan yang baik dalam usus. Oleh karena itu, serat pangan sangat berperan dalam kesehatan dan kondisi penyakit didalam berbagai kelompok populasi (Putri, 2014).

\section{Potensi Pemanfaatan Limbah Ampas Kelapa dari Aspek Ekonomis dan Ekologis}

Dari proses pembuatan minyak kelapa dapat menghasilkan limbah padat berupa ampas kelapa. Potensi ampas kelapa dari home industri pengolahan minyak kelapa sekitar 30\% dari bahan baku (Liptan, 2006 dalam Silondae 2017). Ampas kelapa merupakan limbah industri atau limbah rumah tangga yang sangat potensial untuk digunakan sebagai bahan pangan karena ampas kelapa masih mudah didapatkan dari sisa pembuatan minyak kelapa tradisional dan limbah pembuatan virgin coconat oil (VCO).

Ampas kelapa dengan serat yang cukup tinggi, protein dan lemak memberi peluang untuk dikembangkan menjadi produk olahan yang mempunyai nilai ekonomis yag lebih dari hanya sekedar dibuang atau pakan ternak. Ampas kelapa dapat diolah menjadi tepung dan bisa digunakan sebagai bahan dalam pembuatan produk pangan. Selain itu, pengolahan ampas kelapa menjadi tepung dan bahan pangan lain seperti biscuit, krupuk, tempe, 
kue semprong bertujuan untuk meningkatkan nilai ekonomis dan juga mempunyai prospek pasar yang baik (Putri, 2014; Widiastuti et al., 2015; Rousmauliana dan Septiani, 2019).

Pengolahan limbah ampas kelapa ini menjadi sumber pangan olahan, dapat dilakukan dengan mudah dan sederhana. Seperti misalnya, pembuatan tepung kelapa dari limbah ampas kelapa hanya menggunakan teknologi yang sangat sederhana sehingga mudah diterapkan pada skala kecil dan menengah. Teknologi ini dapat dimanfaatkan oleh produsen produk berbasis ampas kelapa untuk mendapatkan penghasilan tambahan dengan mengolah ampas kelapa menjadi tepung dan sekaligus meminimalisasi produksi limbah.

Meminimalisasi limbah pada industri pengolahan kelapa juga memberi kesempatan pada pengusaha untuk menjual produknya dengan harga kompetitif. Keuntungan lain dari penerapan teknologi pembuatan tepung kelapa pada industri pengolahan kelapa selain memberi pedapatan tambahan juga menurunkan biaya produksi produk roti, kue dan makanan ringan lainnya (Yulvianti et al., 2015).

Dewasa ini limbah ampas kelapa juga dapat digunakan untuk bahan biodiesel maupun bioethanol (Jamaran dan Irawadi, 2014; Khaidir, et al., 2015). Berarti limbah ampas kelapa ini mempunyai potensi juga untuk dikembangkan menjadi bahan bakar yang ramah lingkungan dan sekaligus sebagai solusi dalam mengatasi pencemaran yang diakibatkan oleh penggunaan bahan bakar konvensional dan juga pencemaran dari limbah ampas kelapa itu sendiri apabila dibuang secara sembarangan. Dengan memaksimalkan penggunaan limbah ampas kelapa ini, didapatkan manfaat ekonomi sekaligus juga manfaat ekologisnya.

\section{KESIMPULAN}

Dari pembahasan ini dapat disimpulkan bahwa pemanfaatan limbah ampas kelapa untuk sumber pangan atau bahan substitusi makanan sangat potensial sekali, baik ditinjau dari aspek produktivitasnya, aspek kesehatan, dan sangat bernilai dari segi ekonomis dan ekologisnya.

\section{UCAPAN TERIMA KASIH}

Penulis menyampaikan ucapan terimakasih kepada Rektor Universitas Katolik Santo Thomas, Dekan Fakultas Pertanian, Kepala Prodi Teknologi Hasil Pertanian, Kepala Perpustakaan Universitas Katolik Santo Thomas Medan.

\section{DAFTAR PUSTAKA}

Direktorat Jenderal Perkebunan. 2017. Statistik Perkebunan Republik Indonesia, Jakarta: Kementrian Pertanian.

Jamaran I dan Tun T Irawadi. 2014. Peluang dan Tantangan Pengembangan Bioindustri Kelapa Nasional. Prosiding Konferensi Nasional Kelapa VIII, 2014

Karouw, S dan Rindengan, B. 2008. Potensi Tepung Ampas Kelapa sebagai Sumber Serat Pangan Dan Manfaatnya Untuk Kesehatan. Bulletin Palma No. 342008.

Khaidir, Nasruddin dan Syahputra, D. 2015. Pengolahan Ampas Kelapa Dalam Menjadi Biodiesel Pada Beberapa Variasi Konsentrasi Katalis Kalium Hidroksida (Koh). Jurnal Samudra Vol. 9 No. 2 Mei 2015 pp: 77-91

Mardiatmoko G. 2018. Produksi Tanaman Kelapa (Cocos nucifera L). Fakultas Pertanian Universitas Pattimura.

Murni, R., Suparjo, Ginting, dan Akmal. 2008. Buku Ajar Teknologi Pemanfaatan Limbah Untuk Pakan. Laboratorium Makanan Ternak, Fakultas Peternakan. Universitas Jambi.

Oktaviana, D., Zuprizal dan Suryanto. 2010. Pengaruh Penambahan Ampas Virgin 
Coconat Oil dalam Ransum terhadap Performan dan Produksi Karkas Ayam Broiler. Buletin Peternakan Vol. 34 (3) pp: 159-164.

Prasetyo, AT., Wibowo, A. A., Anand, C., Rahmayani, D. A., Abdurahman, H. 2014. Potensi Limbah Ampas Kelapa (Cocos nucifera L) Sebagai Tepung Substitusi Produk Mococo: Modified Coconut Coocies. Institut Pertanian Bogor.

Putri, M. F. 2014. Kandungan Gizi dan Sifat Fisik Tepung Ampas Kelapa Sebagai Bahan Pangan Sumber Serat. Teknobuga Vol. 1 No. 1 Juni 2014 pp: 32-43.

Rousmaliana dan Septiani. 2019. Identifikasi Tepung Ampas Kelapa terhadap Kadar Proksimat Menggunakan Metode Pengeringan Oven Vol. 1, No. 1, Agustus 2019 pp: 18-31.

Saepulah, A., U. Julita, T. Yusuf dan Cahyanto, 2017. Inovasi Produk Pangan melalui Pemanfaatan Limbah Organik Ampas Kelapa Untuk Meningkatkan Ekonomi Masyarakat Kabupaten Bandung Jawa Barat. Jurnal Istek. Volume X No. 2 Juni 2017 pp: 91-106.

Silondae H, Ratri R. Ifada dan Fira, R. 2017. Potensi Ampas Kelapa Sebagai
Pakan Nutrisi Tinggi. Badan Pengkajian Teknologi Pertanian Sulawesi Utara.

Wardani EN, I Made, Sugitha dan Desak PK Pratiwi. 2017. Pemanfaatan Ampas Kelapa Sebagai Bahan Pangan Sumber Serat Dalam Pembuatan Cookies Ubi Jalar Ungu. Jurnal Itepa. Vol 5 No. 22017 pp: 162-170.

Widiastuti, D., Mulyati, A. H., dan M. Septiani, M. 2015. Karakteristik Tepung Limbah Ampas Kelapa Pasar Tradisional Dan Industri Virgin Coconut Oil (VCO). Jurnal Ekologia. Vol. 15 No.1 April 2015 pp: 29-34.

Yulvianti, M, Ernayati, W, Tarsono, R. Alfian, M. 2015. Pemanfaatan Ampas Kelapa Sebagai Bahan Baku Tepung Kelapa Tinggi Serat Dengan Metode Freeze Drying. Jurnal Integrasi Proses Vol. 5, No. 2 pp: $101-107$. 